\title{
Two types of theories about manipulative communication
}

\author{
Ştefan Vlăduţescu \\ University of Craiova, 13 A. I. Cuza Street, 200585, Craiova, Romania \\ E-mail address: stefan.vladutescu@yahoo.com
}

\begin{abstract}
The study aims to explore and classify the theories of mani ma ur the is is that manipulation constitutes a form of manipulative utilisation of commu catron; $\mathrm{h}$, ma pulation is communication, is manipulative communication. Taking into nt that un action of manipulation the judgement of the manipulated is paralysed, n in wualising he manipulative persuasive intervention, we emphasise that the effect of menta 1 rarysis is . eved by the manipulator coordinating their efforts directly by means of the man pulating message ith indirect influences induced by the situation of manipulation. In this regard one may delimit two types of theories: the theory of message manipulation and theory of situational nipulation. The reality is that manipulation is message-situational and situational-message to the sam tent.

Keywords: communication; manipulative comn message manipulation theory; situational manipulation theory

\section{INTRODUCTION}

In relation to th $\mathrm{cc}$ ion of con araint, manipulation can be characterised as a form of persuasion withen consti. Both interpersonal manipulation and group or social manipulation ay done without straint, without violence, without pressure. Etymologically, "to manipul " orig tes from the French word "manipuler" which means "to handle, to manoeuvre", h sulation neaning "the action to manipulate and its result" (DEX, 1996, p. 597).

"Mà pul" wà ne tactical basic unit of the Roman army. The manipul had a unitary ben. vur cronent meaning of the word "manipular" includes the idea of automatic integra vinto une unit of the group seen as manipul. Manipulation is experienced within the group as ve contagion: the individual does what the group does, they are manipulated not by the grou $\rho$, but by the deed of the group. On the other hand, the deed of the group is imposed by the order of a commander. In this manipulating situation, the commander of manipul is the one manipulating, they are the manipulator.
\end{abstract}




\section{MESSAGE AND SITUATION IN MANIPULATION}

There are two types of theories of manipulation: message and situational theories.

A. The message theory is of communicologic nuance and it affirms that that which triggers manipulation is the message. "The element message, show Newsom and Carrell (Newson D., Carrell B., 2004, p. 74), is often the most important in this process".

Among those who give primary importance to message are Leventhal, Singer, Jones, Wallace Fotheringham, W. J. McGuire, Gleicher and Petty.

Levanthal, Singer and Jones made an experiment, by administrating message to a group and providing therein a possibility to control the situation message was transmitted to another group without making available to it an inst. ion abo how to keep the situation under control. The conclusion of the team as that thess ge prevails in relation to the situation, because the persuasive effect of anxi enic in osage proved to be stronger to the extent where this message circulated a in a do ntrol the situation. When the possibilities to avoid the danger are not ound in mes age which informs them about that danger, the individual prefers not t $/$ about th anger, letting themselves be impacted by that danger. When the messare onta volutions, the individual strengthens to find saving solutions.

Wallace Fotheringham (1966) is one of the first hessage experts, y no defined persuasion as that complex of effects on receivers, that is cause by the mess ge of the persuasive agent.

William J. McGuire (McGuire W.-H., 1973, p 21) show that the message lies at the centre of the persuasion process, performad sequen. seven steps. The first step is presenting the message, imposing the prese followed by the participation of the target, by paying attention: the receiver's t ten an ast be stimulated to the persuasive message. The alert ones shall underctand the in ssage? comprehension. The message must be developed as such as the target wour iccept $i$ and agree with the position stated. The fifth step is retaining the informati con ant transn itted. The sixth and last step is the action.

Gleicher and Petty ho stu un an an an anenic message to gave effect under the conditions where it ovides see ng,ways. They exposed the students to an anxiogenic message about crimi ality the camp o. The message delivered securing expectations. When the students beliey n the dity of the solution conveyed by the message, they favourably evaluated argu nents motivate e solution, whether they were weak or strong. When the expectations relat to the efficiency of resolution appeared to be insufficiently provided, the students $p_{a}$ iention a greater extent on arguments.

niţa so gives a primary importance to message. According to this dist guist $d$ profes 1 , the production of the journalistic text (without losing sight of the imp and focisive factors for the profile of the situation of journalistic comm vation) Is organised according to the message. The elements of the situation of commun in are planned and organised in relation to the transfer of the message. The journalistic effort is efficient if the message has effect. Therefore, under the conditions where the receiver has the possibility "to permanently operate a selection of messages" (Roşca L, 2004 , p. 95), they must be attracted by the propagated message. Taking into account that the "receiver chooses the media text/message knowingly, according to the contractual terms and their scope of expectation" (Roşca L., 2004, p. 94) it is concluded that the "accessibility of messages" (Roşca L., 2004, p. 92) and optimally setting the time and place for "diffusing the messages" (Roşca L., 2004, p. 77) are necessary. Therefore, the message prevails in journalistic communication, and above all, not the situation of journalistic communication. 
Informational expectations triggered by the intellect are then differentiated, which have a cogitative convergence in the need for knowing, self-knowing, understanding, discovering: the need to range (expected information about personalities, models, notabilities in relation to which the consumer of information is intellectually located), the need for novelty (expected information about new discoveries), the need to understand what is happening (acts and deeds, intellectual events) and the need to use the knowledge.

According to Daniela Zeca-Buzura (Zeca-Buzura D., 2005, p. 83), "beyond the information communicated" (...), "the viewer is left at the end with a subjective impression", which is why the communicator's attention must start from an "intention of communinotion" and from a "message" which they would try to create by using the means they har avait

B. The situational theories are rooted in the social psychology and hey clude th the situation is that which has a primary role in manipulation.

The most important representative of the situational theory Alex ycchio. He substantiated his theory in "Les situations de la communication". $H$ fur . einfor d by two studies, which were also translated into Romanian, "Arta de a inf uenţa" (1 Art 9 Anfluence) and "Arta de a comunica" (The Art of Communication) A Mucchic says that "to communicate means to intervene with the purpose to chang the o 's situation" (Muchielli A., 2005, p. 84). According to the Swiss specialist, "a y rd is an the other" (Muchielli A., 2002, p. 11). "The Art of Infly hce" is an "analys ss of the manipulation techniques" the postulate of which is that every word by manipulating the contextual elements of the situation of communication which is necessaril art of rest uctures the situation in order to let arise some significations serving the interest of who speaks them (Muchielli A., 2002, p. 13). Communication is not a t a dion of information, but a construction of significations. The influence is the fu dar tr. phenomenon of communication: "communication means influence" (Muchiell 1., 2082, p. 191). With communication, it is aimed to transmit a meaning whi n ca nly be onfigured in the situation. "To manipulate (or influence), states A. Mucch me us to int rvene (by action or by word, meaning by communication) on the co on or uation of communication. By modifying these elements, the structure o be situatio modified and therefore, also the meaning of the events in progress" (Muchie A 002 , p. 19).

One of the B mian nentatives of the situational theory is Bogdan Ficeac. He starts from the idea t'at "social situa as exercises a significant control on the human behaviour", the individy actic and reactions to stimuli in a given environment being "determined by forces and co, ants spe fic to that environment" (Ficeac B., 2001, p. 30). Under these conditi manip tion s defined situationally thus: "we may speak of manipulation when a cert in so al situa $A$ is premeditatedly created in order to influence the manipulators' reav "s the manipulator" (Ficeac B., 2001, p. 30). definitional draft of the "Dictionary of Sociology" is also classified on the situational direction Mfir C., Vlăsceanu L., 1993, pp. 336 - 337): "by manipulation, it is not intended to understand the situation more correctly and profoundly, but to inoculate a convenient understanding, turning to mislead (which is a form of lie - n.n.) with false arguments, as well as to appealing to non-rational levels". Within the situation, understanding the situation, manipulation is formed as "an action to determine a social actor (person, collectiveness, group) to think and act compatibly with the initiator's interests, and not with their own interests, by using some persuasion techniques which intentionally distort the truth". We do not consider that the action of manipulation occurs in the situation as the target of the action which a person, group, collectiveness forms, that persuasion techniques are used and misleading prevails 
therein. In addition, the authors of the dictionary differentiate manipulation from the "rationally convincing type of influence" We consider that this situational definition, beyond its value and utility, falls into error when it concludes that a form of persuasion uses "persuasion techniques", and not "techniques of rationally convincing". This is because we, in other words, are told that a form of persuasion does not use influences of conviction type. On the other hand, a message element is also drawn into the definition when showing: "the actual intentions of that who transmits the message remain insensitive to its patrimony". Of course, taken as components-forms of persuasion, manipulation, propaganda, disinformation, intoxication and rumour have something in common: persuasion. If we want manipulation to occupy a ronoe in persuasion, then we need do proceed at its segregation of propaganda and advert Manipulation is however outside the propaganda, outside advertising. Manipu on can oce anywhere and anytime (Stavre, 2011). We can interconnect them only when ve th to deta characteristics of the over-ordered persuasion or when we seek to diffe ntiate the s if oy comparison.

According to many specialists the action of manipulation me s to cive the military, economical or political) opponent regarding the real intentic s and w ening their will through actions of disinformation. From our point of view, no ulation is action in the operational-procedural technology of which operations such as the (deceit is a form of the lie), seduction, fiction and myth are classified. An opers "uns achieve "ough "actions", that manipulation is done through actions of disinformati $n$ and that the objective of manipulation is to deceit the opponent.

C. The message direction is also juct as secluo

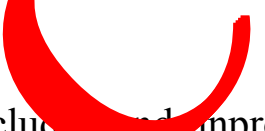
manipulation is an influencing intervention asive type, which by using a manipulating message and valorising a situation of manip lati, crmines the change of thinking and current action of a target (person, graip, colle iveness). Concerning the source and target of manipulation, one may say that nyo can be target or a source. Depending on the type of manipulation (interpersonal o val) he target/s individualised specifically.

Cristian Florin Pop co recent years it has been proven that persuasion and influence (...) are trinsic to edia communication (Popescu C.F., 2002, p. 172), understanding that th mo would be efined as influencing and persuasive. C.F. Popescu is not interested to bu mation, considering that the term manipulation would not be appropriate for certain "histo 1 circumstances: world wars, the Cold War, totalitarian regimes, wb the cres are the indoctrination and all that belongs to psychological war" (Popescu C. P., 2, p. 1')

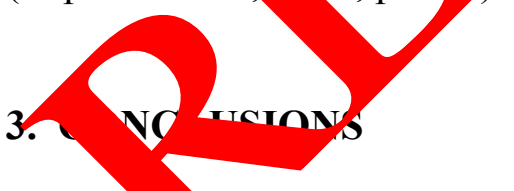

Mat yation uses the pseudo-information (that apparent information which, according to Andreas Freund (Freund A., 1991, p 263) is outlined by obscurantism and/or hidden advertising) para-information (minor and diluted version of informing which, as shown by A. Freund (Freund A., 1991, 263), consists in replacing authentic information, minor, sensational and customised aspects hereof), under-information and over-information. That is, manipulation fully uses ex-information. 


\section{ACKNOWLEDGMENT}

This work was partially supported by the grant number 33C/2014, awarded in the internal grant competition of the University of Craiova.

\section{References}

[1] D. Newson, B. Carrell (2004). Redactarea materialelor de relaţii publice. Iaşi: Editura Polirom.

[2] Andrzej Borowski, International Letters of Social and Humanistic Science 4 (2014) 7-17.

[3] W.-J. McGuire (1973). Persuasion, resistance, and attitude change in Handboc communication. Chicago: Rand McNally.

[4] Sebastian Kot, Janusz Grabara, Michal Kolcun, Internationa Lewers Focial hd Humanistic Sciences 15 (2014) 1-6.

[5] Veronica Ion (2012). The religiuos changes of the po mmu Balkan societies. Revista de Stiinţe Politice.

[6] Daniela Rovenţa-Frumuşani (2005). Analiza dis ursului. Ipoteze şl ipostaze. Bucureşti: Tritonic.

[7] C. Zamfir, L. Vlăsceanu (1993). Dicţionar de soct

[8] Bogdan Ficeac (2001). Tehnici de manip Tar Titia a patra. Bucureşti: Nemira.

[9] D. Zeca-Buzura (2005). Jurnalismul de te iziune. Iaşi: Polirom.

[10] Ștefan Vlăduțescu, Intern lona etters of cial and Humanistic Sciences 24 (2014) 86-94.

[11] Andrzej Borowski nternatio, Letters of Social and Humanistic Sciences 14 (2014) $33-41$.

[12] M. Colhon (V) Aut tic Lexical Alignment between Syntactically Weak Related Languag s. Ap lication to cnglish and Romanian. In Computational Collective Intelli e. Tonologies and Applications (pp. 266-275). Springer Berlin Heidelberg.

[13] A. Mucch (2005). Arta de a comunica. Metode, forme, psihologia situaţillor de

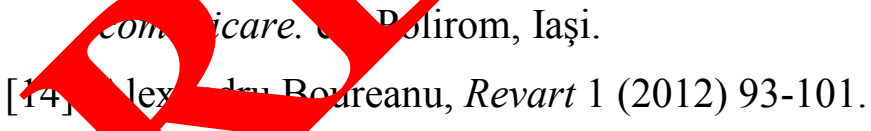

[15] M. G. Craig, Journal of Studies in Social Sciences 8(1) (2014).

[16] A. T staru, M. Avram, International Letters of Social and Humanistic Sciences 13 (2014) 79-88.

[17] Andrzej Borowski, International Letters of Social and Humanistic Sciences 4 (2013) $70-74$.

[18] L. Roşca (2004). Producţia textului jurnalistic. Editura Polirom, Iaşi.

[19] I. C. Dima, Ş. Vlăduţescu, European Journal of Business and Social Sciences 6(1) (2012) 27-33. 
[20] A. Borowski, International Letters of Social and Humanistic Sciences 11 (2014) 1-168

[21] L. Roşca (2012). La sphère publique: la démocratisation de la vie sociale et politique et les médias en Roumanie. Tritonic.

[22] Cristian Florin Popescu (2002). Dicţionar explicativ de Jurnalism, Relaţii Publice şi Publicitate. Bucureşti: Tritonic.

[23] R. Y. Papancheva, K. A. Dimitrova, K. N. Manev (2010). Teaching IT in the Primary School-Some Aspects of Propaedeutics of Informatics Knowledge. In CSEDU (2) (pp. 185-188).

[24] Mihai Coman, Journalism Studies 1(1) (2000) 35-56.

[25] Andrezj Borowski, International Letters of Social and Humanistic Sc nces 2014) 110-121.

[26] G. Dibra, L. Kashahu, J. Bushati, M. Priku (2014). Learning an adu Europ an Scientific Journal. Research 1(9) (2012) 1-11.

[28] M. Nowicka-Scowron, I. C. Dima, Ş. Vlăduţescu inm nationa ynal of Management Sciences and Business Research (8) (2012) 27-35.

[29] A. Erich, E. Tîrziman (2007). Informaţie şi do nent în soc etatea cunoaşterii. Ed. Bibliotheca.

[30] C. Cace, S. Cace, S. Cojocaru, L. Sfetc 2), Social economy in Romaniachallenges and perspectives. Transylva an of Administrative Sciences.

[31] A. Freund (1991). Journalisn mésinfo mation. La pensée sauvage.

[32] Ştefan Vlăduţescu, Amer n Int inational Journal of Contemporary Research 3(10) (2013).

[33] V. A. Enăchescu Damasaru, vista de Management Comparat Internaţional/ Review of Inter atio, Comparcave Management 14(4) (2013) 644-653.

[34] Cristina An ca Păiuşescu, ^a Duţă, Dreptul comunicării. Consideraţii teoretice şi legislat relevo +ăa. "Edity,a Universitară" Publishing House, Bucharest, 2011.

[35] Camelia. dolescu. 1997). Le trust en droit anglais. (Doctoral dissertation).

[36] Trá oşca 1. tical and Applied Economics 1(1) (2012) 127.

[31, an D...candra Dascălu (2014). Etude sur les passions dans la culture ancienne et erne. Craiova: Editura Universitaria.

[38] Andà Adulescu (2008). Bref aperçu des grands courants en traduction: théories européennes et américaines. Craiova: Editura Universitaria.

[39] Andrzej Borowski International Letters of Social and Humanistic Sciences 7 (2013) 113-118.

[40] Andrzej Borowski, International Letters of Social and Humanistic Sciences 11 (2013) 100-105.

[41] Okezie A. Ihugba, Alex Odii, A. C. Njoku, International Letters of Social and Humanistic Sciences 5 (2014) 21-34. 
[42] Cristina Coman (2000). Relaţiile publice şi mass-media. Iaşi: Polirom.

[43] Janusz Grabara, Michal Kolcun, Sebastian Kot, International Journal of Education and Research 2(2) (2014).

[44] Ştefan Vlăduţescu, European Scientific Journal 9(32) (2013).

[45] Aurika Komsaare, International Journal of Learning 16(6) (2009).

[46] Aurelia Traistaru (2013). Consolidation of the green marketing profile in current austerity period. Jokull.

[47] J. H. Gasderell, International Letters of Social and Humanistic Science 22 2014) 8

[48] Ştefan Vlăduţescu, International Journal of Education and Research 1(12) 013).

[49] C. M. Bunăiaşu, Procedia-Social and Behavioral Sciences 116 (2014) 1121-1

[50] Ioana Coman, Peter Goss, The International Journal of Press/Po cs ( 012$)$.

[51] Andrezj Borowski, International Letters of Social and Hur anistic S. ces 3 ,2013) 69-74.

[52] Ștefan Vlăduțescu, International Letters of Social a Uuman Sciences 10 (2014) 100-106.

[53] Jason L. Powell, International Letters of Socia and Humani tic Sciences 7 (2014) 22-30.

[54] Ștefan Vlăduțescu, International Lette of Social _manistic Sciences 7 (2014) 8-13.

[55] Jason L. Powell, International Letters of cial a,d Humanistic Sciences 16(2) (2014) 177-183.

[56] Jason L. Powell, Interngen l L ters of Scial and Humanistic Sciences 17(1) (2014) 1-60. 